\title{
Response of sedimentary bacteria in a Louisiana salt marsh to contamination by diesel fuel
}

\author{
Kevin R. Carman ${ }^{1, *}$, Jay C. Means ${ }^{2}$, Steven C. Pomarico ${ }^{1}$ \\ ${ }^{1}$ Department of Zoology \& Physiology, ${ }^{2}$ Veterinary Physiology, Pharmacology \& Toxicology, Louisiana State University, \\ Baton Rouge, Louisiana 70803-1725, USA
}

\begin{abstract}
In a $28 \mathrm{~d}$ microcosm study, we examined the effects of diesel-contaminated sediment on the sedimentary bacterial community of a Louisiana (USA) salt marsh that has been chronically exposed to petroleum hydrocarbons for decades. Diesel contaminants in microcosms as determined from polycyclic aromatic hydrocarbon ( $\mathrm{PAH}$ ) concentration ranged from 0.55 to $55 \mathrm{ppm}$ (dry weight). Bacterial metabolism (incorporation of ${ }^{14} \mathrm{C}$-acetate and ${ }^{3} \mathrm{H}$-leucine) and bacterial abundance were not affected by diesel-contaminated sediment at any concentration. Bacterial degradation of ${ }^{14} \mathrm{C}$ phenanthrene, however, increased in direct proportion to the amount of diesel-contaminated sediment added. Ambient sediment also exhibited significant capacity to degrade PAH. The half life of phenanthrene (based on ${ }^{14} \mathrm{C}$-phenanthrene-degradation experiments) ranged from $137 \mathrm{~d}$ in ambient sediments to $4.5 \mathrm{~d}$ in sediment chronically exposed to high levels of diesel-contaminated sediments for $28 \mathrm{~d}$. Two- and three-ring PAH, including naphthalenes, phenanthrenes, and dibenzothiophenes, constituted the bulk of PAH composition of diesel and were rapidly metabolized. Alkylated PAH were also readily metabolized. The rapid removal of $\mathrm{PAH}$ suggests that even if the marsh were exposed to chronically high levels of petroleum hydrocarbons, chemical evidence of the contaminants would not be detected in sediments. Collectively, these results are consistent with the hypothesis that the bacterial community in this salt marsh has adapted to chronic exposure to petroleum hydrocarbons.
\end{abstract}

KEY WORDS: Bacteria $\cdot$ Sediments $\cdot$ PAH - Diesel $\cdot$ Petroleum

\section{INTRODUCTION}

It is estimated that 1.7 to $8.8 \times 10^{6} \mathrm{t}$ of petroleum hydrocarbons are released into the marine environment annually; $10 \%$ or more of this input may be from refined petroleum such as fuel oils (National Research Council 1985a). Among the various refined petroleum products, diesel fuel is considered to be highly toxic because it is enriched with polycyclic aromatic hydrocarbons (PAH; approximately 30 to $40 \%$; National Toxicology Program 1986), the most toxic component of petroleum hydrocarbons (Clark 1989, Kennish 1992). Because of its toxicity and widespread use in military, commercial, and recreational vessels, diesel fuel represents a potentially significant contaminant to aquatic environments. Most of the PAH released into aquatic

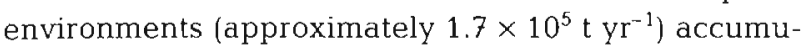

\footnotetext{
•E-mail: zocarm@lsuvm.sncc.lsu.edu
}

lates in estuaries (Kennish 1992). As opposed to lighter fuels such as gasoline, many of the PAH in diesel are of a sufficiently high molecular weight that they do not readily evaporate (Clark 1989), but become associated with fine hydrophobic particles and are ultimately transported to the benthos (Connell \& Miller 1984). Salt marshes are low-energy environments where these particles are likely to accumulate (Little 1987). Salt marshes are also highly productive and serve as nursery grounds for many commercially and economically important species. Because of these physical and biological characteristics, salt marshes are considered to be particularly susceptible to chronic and/or catastrophic inputs of petroleum hydrocarbons (National Research Council 1985b, Samiullah 1985).

Several studies have examined the response of benthic microbial communities to individual PAH (Bauer \& Capone 1985a, b, Bauer et al. 1988, MacGillivray \& Shiaris 1994) or crude oil (Alexander \& Schwarz 1980, 
Griffiths et al. 1981a, b, Heitkamp \& Cerniglia 1988), but few have considered the effects of refined fuels (Jamison et al. 1976). Further, while it is recognized that microorganisms play a critical role in the breakdown of hydrocarbons, the impact of hydrocarbons on the metabolism and abundance of natural microbial communities is poorly understood (Bartha \& Atlas 1987). Crude oil, for example, has been shown to enhance (Bunch 1987), reduce (Griffiths et al. 1981a), or have no effect (Bauer \& Capone 1985a, Wyndham 1985) on total abundance of sedimentary bacteria. Studies of individual aromatic compounds typically detect no significant influence on total bacterial abundance (Bauer \& Capone 1985a). Bacterial communities also vary considerably in their metabolic response to petroleum hydrocarbons (Alexander \& Schwarz 1980, Griffiths et al. 1981a, b, Bauer \& Capone 1985a, Bauer et al. 1988). Previous chronic exposure to hydrocarbons has been proposed as a partial explanation for variability in bacterial response to petroleum hydrocarbons (Griffiths et al. 1981b).

This report is part of a study in which microcosm experiments were performed to examine the effects of diesel fuel on the benthic food web of a coastal salt marsh. Future papers will consider the impact of diesel on microalgal activity and abundance, meiofaunal grazing, and meiofaunal community structure. Here, we examine the influence of diesel-contaminated sediments on the benthic bacterial assemblage in terms of abundance, metabolic activity, and capacity to degrade PAH.

\section{MATERIALS AND METHODS}

Study site. The research was performed using sediments from Terrebonne Bay estuary $\left(29^{\circ} 15^{\prime} \mathrm{N}, 91^{\circ}\right.$ $\left.21^{\prime} \mathrm{W}\right)$ near the Louisiana Universities Marine Consortium Laboratory (LUMCON) at Cocodrie, LA, USA. Tidal range in the estuary is approximately $0.3 \mathrm{~m}$ and salinity ranges from 4 to $26 \mathrm{ppt}$. The estuary is a highly productive salt marsh that is dominated by the cord grass Spartina alterniflora. Sediment has a median grain size of $38 \mu \mathrm{m}$ and is composed primarily of silts $(41 \%)$ and clays (17\%) (Chandler \& Fleeger 1983). Organic content of sediment is approximately $2.5 \%$. The study site is located in a region of intense hydrocarbon production and drilling activity, and commercial and recreational boat traffic is high. These combined factors lead to a high probability that the marsh experiences chronic exposure to both refined and crude hydrocarbons.

Experimental design. The effects of diesel fuel on sedimentary bacteria were examined using intact, natural sediment collected in cylindrical microcosms from the study site. Microcosms were maintained in the LUMCON laboratory under controlled temperature and light conditions. Experimental treatments consisted of the daily addition to microcosms of small doses of diesel-contaminated sediment, and bacterial responses were determined over a $28 \mathrm{~d}$ period.

Microcosm experiments were performed with a $2 \times$ $4 \times 5$ factorial design, with 2 wet tables (as blocks), 4 exposure times, and 5 diesel treatments as factors. Each diesel $\times$ time combination was replicated twice in both wet tables. Microcosms were constructed of $15.2 \mathrm{~cm}$ i.d. PVC pipe with windows covered with Nitex mesh $(62 \mu \mathrm{m})$ to allow exchange of water. At low tide on 22 May 1994, 80 microcosms of exposed unvegetated sediment were collected by hand from mud flats surrounded by Spartina alterniflora marsh. Microcosms were gently pushed into the sediment to a depth of $15 \mathrm{~cm}$, mud was excavated from the outside of the microcosm, and a form-fitting base was placed on the bottom. Intact microcosms were removed from the mud flat and transported to the LUMCON facility. Forty microcosms were randomly assigned to each of the 2 wet tables.

Microcosms were irrigated individually using a drip system. Ambient marsh water was filtered $(5 \mu \mathrm{m})$ and pumped into a $1200 \mathrm{l}$ holding tank. Water was aerated by continuous recirculation. Water was pumped from the holding tank to a $60 \mathrm{l}$ head tank, which fed the drip system. Water was dripped into microcosms at a rate of approximately $1 \mathrm{l} \mathrm{h}^{-1}$, sufficient to exchange the overlying water approximately once every hour.

The treatments consisted of the addition to microcosms of sediment spiked with 3 levels of diesel (High, Medium, and Low), and 2 types of controls; in one control (Cont1), no sediment was added to microcosms, in the second control (Cont2) 'uncontaminated' sediment was added to microcosms. Four replicate microcosms ( 2 from each wet table) of each of the 5 treatment levels (20 total microcosms) were harvested at each of 4 time intervals $(0,7,14$, and 28 d) following a previously determined randomization schedule.

Diesel-contaminated sediments. Surficial sediments (top $2 \mathrm{~cm}$ ) were collected from the marsh and processed following the procedure of Chandler (1986), which results in sterile sediment consisting of particles $<62 \mu \mathrm{m}$. Diesel fuel was obtained from a commercial vendor. Two liters of processed sediments and $600 \mathrm{ml}$ of diesel were placed in an amber 41 bottle and tumbled for $10 \mathrm{~d}$. The bottle was then removed from the tumbler and sediment allowed to settle overnight. Diesel was aspirated from the bottle and $1 \mathrm{l}$ of $15 \mathrm{ppt}$ artificial seawater (ASW) was added. The mixture was tumbled again (overnight), allowed to settle, and the supernatant aspirated. This procedure was repeated 3 times (total of 4 rinses). The sediment-water slurry 
was transferred to $35 \mathrm{ml}$ glass centrifuge tubes and centrifuged at $1700 \times g$ for $3 \mathrm{~min}$. The supernatant was removed and replaced with fresh ASW. Sediment and water were mixed thoroughly then recentrifuged. The supernatant was decanted again, and the process was repeated for a total of 4 rinses via centrifugation. Sediment was then recombined into a single batch and mixed to assure homogeneity. A sediment sample was removed from the batch, and total PAH (described below) was determined to be 687 ppm (dry weight). Contaminated sediment was then diluted with ambient sediment (processed as described above) to achieve PAH concentrations of 550, 55, and $5.5 \mathrm{ppm}$ (dry weight). Diluted contaminated sediments were added to microcosms as described below with the objective of achieving final added concentrations in the top $1 \mathrm{~cm}$ of sediment of 55 (High), 5.5 (Medium), and 0.55 (Low) ppm.

At the beginning of the experiment, microcosms were dosed by adding sediment sufficient to create a $1 \mathrm{~mm}$ thick layer of sediment on the microcosm surface. This was accomplished by loading $30 \mathrm{ml}$ plastic syringes with $17.8 \mathrm{ml}$ of contaminated (or control) sediment, then slowly dispensing the sediment into the water overlying the microcosm (after removal of drip tubes) in a uniform manner. Sediment settled onto the microcosm surface within approximately $1 \mathrm{~h}$, at which time microcosm drip tubes were replaced. Within approximately $2 \mathrm{~h}$, surface topography (tubes, burrows, and tracks) from resident meiofauna and macrofauna was apparent. On each subsequent day, microcosms were dosed with $1.8 \mathrm{ml}$ of sediment, sufficient to create a $0.1 \mathrm{~mm}$ sediment layer on the surface of microcosms

Total PAH in sediment used to dose High treatments, as well as sediment in the top $1 \mathrm{~cm}$ of Day 0 and Day 28 High and Medium treatments, were determined with an Iatroscan (Ackman et al. 1990). For Iatroscan analysis, 10 to $34 \mathrm{~g}$ of sediment was extracted thrice in $70 \mathrm{ml}$ dichloromethane, with $25 \mathrm{~g}$ of solvent-rinsed $\mathrm{Na}_{2} \mathrm{SO}_{4}$ added in the first extraction. ${ }^{14} \mathrm{C}$-phenanthrene was added as an internal standard to determine extraction efficiency. Combined extracts were passed through a column containing $0.5 \mathrm{~g}$ solvent-rinsed $\mathrm{Na}_{2} \mathrm{SO}_{4}$, collected in a $250 \mathrm{ml}$ round-bottom flask, and concentrated by rotary evaporation to $1-2 \mathrm{ml}$. The concentrated extract was transferred with rinsing to a $13 \times$ $100 \mathrm{~mm}$ tube then dried under $\mathrm{N}_{2}$ and stored in the freezer until further analysis. The extract was dissolved in $\mathrm{CHCl}_{3}$ and fractionated by solid phase extraction (SPE) chromatography on a silica column (500 $\mathrm{mg}$, Whatman) with $5 \mathrm{ml} \mathrm{CHCl}_{3}$. This fraction was dried under $\mathrm{N}_{2}$, dissolved in toluene and fractionated by SPE chromatography on a silica column (500 mg) with $5 \mathrm{ml}$ of toluene. The toluene fraction was dried then dissolved in a $50-100 \mu \mathrm{CHCl}_{3}$ and duplicate 1-2 $\mu$ l samples were spotted on a Chromarod (SIII). Chromarods were dried under active vacuum after each development described below. Chromarod developments were carried out at $35^{\circ} \mathrm{C}$ as follows: (1) toluene for $5 \mathrm{~min},(2)$ toluene for $5 \mathrm{~min}$, (3) hexane for 30 min. Rads were analyzed using an Iatroscan MK-5 TLC/FID analyzer. The PAH peaks were quantified by comparison to an external calibration curve generated using a standard consisting of a mixture of $16 \mathrm{PAH}$ ranging from naphthalene (2 rings) to benzo( $g, h, i)$ perylene (6 rings) (Supelco). Final concentrations were calculated with a correction for recovery of ${ }^{14} \mathrm{C}$-phenanthrene.

Undiluted contaminated sediment and the top $1 \mathrm{~cm}$ of sediment from 2 replicates of each treatment on Day 0 and Day 28 were analyzed by gas chromatography/mass spectrometry (GC/MS) for PAH content (Means \& McMillin 1993). Sediments were extracted in glass ointment jars containing $\sim 4 \mathrm{~g}$ wet sediment after removing $\sim 0.5 \mathrm{~g}$ for moisture determination. $\mathrm{Na}_{2} \mathrm{SO}_{4}$ (30 g) was mixed into each sample and added to an empty container to create a reagent blank. Pesticidegrade dichloromethane (DCM, $40 \mathrm{ml}$ ) was added to each jar along with 15 hl of a mixture of deuterated

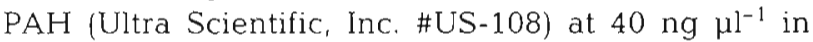
hexane. Open jars were placed in an ice-cooled sonicating bath for $12 \mathrm{~min}$. Solvent was decanted through solvent-rinsed $\mathrm{Na}_{2} \mathrm{SO}_{4}$ into a rotavap flask, and DCM extraction repeated twice more. Combined extracts were concentrated to $\sim \mathrm{ml}$, transferred with rinsing to a $4 \mathrm{ml}$ vial, and further concentrated, with exchange to hexane, to $200 \mathrm{\mu l}$ using a dried nitrogen stream. Activated fine-granular copper (MacLeod et al. 1985) was added in excess to remove sulfur interference.

Extracts were analyzed by GC/MS using a HewlettPackard 5890/5970B Mass Selective Detector (MSD) equipped with a $30 \mathrm{~m}$ by $0.25 \mathrm{~mm}$ i.d., $0.25 \mu \mathrm{m}$ DB-5 film capillary column ( $\mathrm{J} \& \mathrm{~W}$ Scientific, Inc.). The GC was programmed from 50 to $300^{\circ} \mathrm{C}$ using 2 temperature ramps over a period of $60 \mathrm{~min}$. The MSD was operated in selected-ion mode. Response calibration was achieved using a mixture of authentic reference stan-

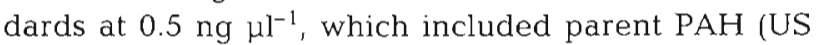
106, Ultra Scientific), deuterated compounds (see above), and 42 alkylated naphthalenes, dibenzothiophenes, and phenanthrenes (Chiron Laboratories A.S., Norway). 2-Fluorobiphenyl was added to the extracts immediately prior to analysis to serve as an instrumental internal standard. Final concentrations were calculated with correction for recovery of the deuterated surrogate standards added during extraction.

Direct counts. Bacterial abundance in the top $1 \mathrm{~cm}$ of sediment was determined from acridine orange direct counts (AODC; Carman 1993). This procedure in- 
cluded separation of bacteria from sediments by blending sediments in $0.01 \%$ sodium pyrophosphate. The resulting supernatant was stained with $0.04 \%$ acridine orange for $2 \mathrm{~min}$, and bacteria were enumerated (Hobbie et al. 1977).

${ }^{14} \mathrm{C}$-acetate incorporation. Bacterial activity was measured by administering ${ }^{14} \mathrm{C}$-acetate into sediment cores ( $1.7 \mathrm{~cm} \mathrm{i.d.)} \mathrm{and} \mathrm{following} \mathrm{the} \mathrm{label} \mathrm{into} \mathrm{bacterial}$ membrane lipids (phospholipids) and lipid storage products (poly- $\beta$-hydroxyalkanoates, PHA; Findlay \& White 1987). Acetate was injected approximately $2 \mathrm{~mm}$ below the sediment-water interface through a siliconsealed slit on the side of the core with a $50 \mu$ l syringe (Hamilton; Dobbs ef al. 1989). A $33.4 \mathrm{kBq}$ quantity of $\left[1,2-{ }^{14} \mathrm{C}\right]$ acetate (dissolved in $22 \mu \mathrm{l} \mathrm{ASW}$; specific activity $4.0 \mathrm{GBq} \mathrm{mmol}^{-1}$ ) was added to each core and incubated in the dark (to prevent photosynthetic fixation of respired ${ }^{14} \mathrm{CO}_{2}$ ) for $5 \mathrm{~h}$. Water overlying the sediment was discarded, and the top $1 \mathrm{~cm}$ of sediment was extruded into a glass $50 \mathrm{ml}$ tube containing $25 \mathrm{ml}$ of modified Bligh-Dyer Solution (White et al. 1979). Bulk lipids were extracted and then fractionated into neutral, phospho-, and glycolipids (which contain PHA)
(Guckert et al. 1985) and assayed for radioactivity. Controls were injected with ${ }^{14} \mathrm{C}$-acetate and then immediately harvested as described above. Data were expressed as dpm ${ }^{14} \mathrm{C}$ incorporated after correction for controls.

${ }^{3} \mathrm{H}$-leucine incorporation. Cores of sediment $(1.7 \mathrm{~cm}$ i.d.) were collected from microcosms on Day 28 only and injected with $405 \mathrm{kBq}(22 \mu \mathrm{l})$ of L-[4,5- $\left.{ }^{3} \mathrm{H}\right]$ leucine (American Radiolabeled Chemicals, Inc.; $2.2 \mathrm{GBq}$ $\mathrm{mmol}^{-1}$ ) as described above for ${ }^{14} \mathrm{C}$-acetate incubations. Sediments were incubated for $45 \mathrm{~min}$, after which the water overlying the sediment was discarded and the top $1 \mathrm{~cm}$ of sediment was extruded into a plastic bag. Sediment was then frozen and stored in liquid nitrogen until further processing. Controls were injected with ${ }^{3} \mathrm{H}$-leucine and immediately frozen. Incorporation of ${ }^{3} \mathrm{H}$ into protein was determined after an acid/base hydrolysis procedure to separate protein from other macromolecules (Carman et al. 1988). Data were expressed as $\mathrm{dpm}{ }^{3} \mathrm{H}$ incorporated after correction for controls

PAH metabolism. Bacterial metabolism of PAH was examined with a modified version of the procedure

Table 1. Concentrations of parent and alkylated PAH as determined by GC/MS analysis. Diesel: sediment that was contaminated with diesel and added to microcosms in various dilutions (see text for further details). Control: the average of both types of control microcosms (2 samples each from Cont1 and Cont2). Low, Medium, and High: the 3 diesel treatments. Values are ppm (dry weight) and are the average of 2 replicates. Nap $=$ naphthalene $;$ Phen $=$ phenanthrene $;$ DBT $=$ dibenzothiophene. $\%$ alkylated $=$ proportion of total PAH that contained 1 or more alkyl side chains

\begin{tabular}{|c|c|c|c|c|c|c|c|c|c|}
\hline \multirow[t]{2}{*}{ Compound } & \multirow[t]{2}{*}{ Diesel } & \multicolumn{2}{|c|}{ Control } & \multicolumn{2}{|c|}{ Low } & \multicolumn{2}{|c|}{ Medium } & \multicolumn{2}{|c|}{ High } \\
\hline & & Day 0 & Day 28 & Day 0 & Day 28 & Day 0 & Day 28 & Day 0 & Day 28 \\
\hline Nap & 2601 & 3 & 4 & 0 & 2 & 12 & 0 & 2 & 8 \\
\hline C1-Nap & 44054 & 2 & 2 & 0 & 2 & 90 & 0 & 47 & 5 \\
\hline C2-Nap & 143537 & 2 & 1 & 0 & 1 & 395 & 0 & 186 & 8 \\
\hline C3-Nap & 141640 & 7 & 6 & 0 & 10 & 1412 & 0 & 944 & 132 \\
\hline C4-Nap & 84171 & 7 & 5 & 0 & 8 & 3717 & 0 & 3274 & 609 \\
\hline Fluorene & 6843 & 0 & 3 & 1 & 0 & 8 & 0 & 2 & 1 \\
\hline Phen & 17321 & 7 & 9 & 19 & 2 & 54 & 18 & 39 & 614 \\
\hline C1-Phen & 53680 & 5 & 8 & 41 & 3 & 209 & 49 & 280 & 581 \\
\hline C2-Phen & 56659 & 5 & 10 & 85 & 3 & 420 & 68 & 1314 & 1189 \\
\hline C3-Phen & 38957 & 6 & 13 & 95 & 5 & 346 & 83 & 1210 & 1535 \\
\hline DBT & 5169 & 0 & 1. & 0 & 0 & 12 & 0 & 17 & 26 \\
\hline C1-DBT & 23930 & 1 & 52 & 2 & 0 & 105 & 0 & 155 & 210 \\
\hline C2-DBT & 52212 & 6 & 12 & 46 & 6 & 427 & 15 & 1693 & 1175 \\
\hline Fluoranthene & 825 & 49 & 25 & 37 & 18 & 87 & 61 & 41 & 46 \\
\hline Pyrene & 3839 & 52 & 26 & 93 & 29 & 97 & 97 & 169 & 212 \\
\hline Benzanthracene & 105 & 11 & 98 & 19 & 34 & 37 & 43 & 11 & 34 \\
\hline Chrysene & 26 & 39 & 32 & 52 & 12 & 55 & 22 & 31 & 15 \\
\hline Benzo(b)fluoranthene & 7 & 41 & 29 & 45 & 44 & 66 & 59 & 25 & 18 \\
\hline Benzo(k)fluoranthene & 2 & 5 & 20 & 30 & 40 & 26 & 39 & 2 & 12 \\
\hline Benzo(a)pyrene & 5 & 13 & 14 & 21 & 13 & 34 & 37 & 6 & 12 \\
\hline Total parent & 48548 & 228 & 287 & 323 & 210 & 549 & 374 & 349 & 1000 \\
\hline Total alkylated & 638841 & 36 & 67 & 269 & 38 & 7119 & 214 & 9101 & 5442 \\
\hline$\%$ alkylated & 92.9 & 13.5 & 18.8 & 45.5 & 15.3 & 92.8 & 36.4 & 96.3 & 84.5 \\
\hline Total PAH & 687389 & 264 & 354 & 592 & 248 & 7668 & 587 & 9450 & 6442 \\
\hline
\end{tabular}


described by MacGillivray \& Shiaris (1994). Microcosm sediment was sampled with a $3 \mathrm{cc}$ syringe core, and the top $1 \mathrm{~cm}\left(1 \mathrm{~cm}^{3}\right)$ was extruded into sterile, $35 \mathrm{ml}$ serum bottles. Nine $\mathrm{ml}$ of $0.45 \mu \mathrm{m}$ filtered marsh water was added to bottles. Nine $\mathrm{ml}$ of $2 \%$ formaldehyde was added to controls. $\left[9-{ }^{14} \mathrm{C}\right]$ phenanthrene (Sigma, 307 $\mathrm{MBq} \mathrm{mmol}^{-1}$ ) was solubilized in ethanol, and $10 \mu \mathrm{l}$ (26.3 kBq; $0.085 \mu$ mol) was added to serum bottles. Serum bottles were capped with a rubber stopper through which a small plastic cup containing fluted Whatman \#1 filter paper was inserted. Bottles were placed on a shaker table and incubated in the dark at $27^{\circ} \mathrm{C}$ for $72 \mathrm{~h}$. Phenethylamine $(0.1 \mathrm{ml})$ was injected into the wick, and $1.0 \mathrm{ml}$ of $1 \mathrm{~N} \mathrm{HCl}$ was added. Acidified samples were incubated overnight, after which wicks were removed and assayed for radioactivity. Data were expressed as percent ${ }^{14} \mathrm{C}$-phenanthrene converted to $\mathrm{CO}_{2}$ after subtraction of control values. Radioactivity recovered in control wicks averaged $1.3 \%$ (range 0.6 to $2.5 \%$ ) of the total radioactivity added. Radioactivity in controls ranged from an average of $51 \%$ of radioactivity in all experimental values on Day 0 to $<4 \%$ of radioactivity in High treatments on Days 14 and 28 .

\section{RESULTS}

\section{PAH composition}

Absolute concentrations of major PAH classes are summarized in Table 1. The most abundant classes of $\mathrm{PAH}$ in diesel-contaminated sediment were naphthalenes, phenanthrenes, and dibenzothiophenes (DBT). Alkylated PAH made up $93 \%$ of the total PAH. The high proportions of naphthalenes, phenanthrenes, DBT and alkylated PAH are typical of refined petroleum hydrocarbons (National Research Council 1985c). To examine compositional differences in PAH among treatments, proportional $\mathrm{PAH}$ abundances were calculated (Steinhauer \& Boehm 1992). The concentration of each compound was expressed as a fraction of the compound with the highest concentration. For example, in diesel-contaminated sediment used to dose microcosms, C2-naphthalenes had the highest concentration (Table 1) and all other PAH were expressed as a fraction of $\mathrm{C} 2$-naphthalene concentration (Fig. 1). In comparison to diesel-contaminated sediment, ambient sediment was relatively depleted in 2- and 3-ring $\mathrm{PAH}$, and most PAH was in the form of 4- and 5-ring compounds (Fig. 1).

Composition of PAH in Day 0 microcosms was variable, but generally reflected that of the added dieselcontaminated sediment (Table 1, Fig. 2). In High (Fig. 2C) and Medium (Fig. 2B) treatments, naphtha-

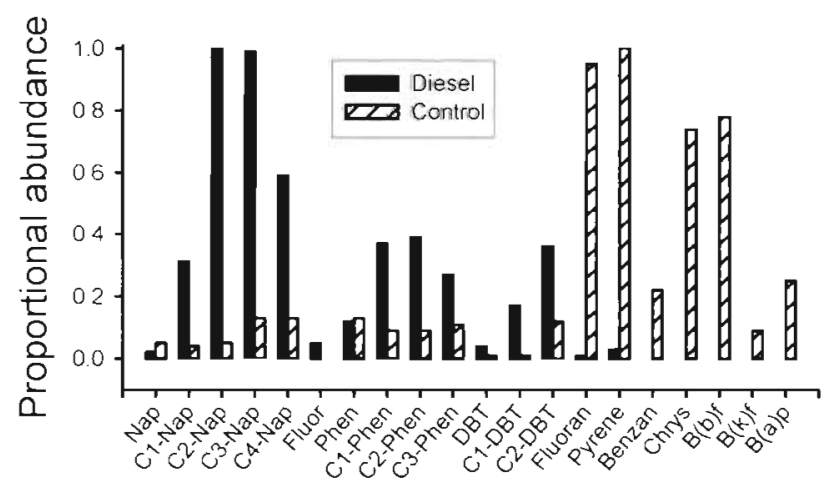

Fig. 1. Proportional abundance of major groups of PAH in diesel-contaminated and control (ambient) sediment. Nap = naphthalene, Fluor $=$ fluorene, Phen = phenanthrene, $\mathrm{DBT}=$ dibenzothiophene, Fluoran = fluoranthene, Benzan = benzanthracene, Chrys = chrysene, $\mathrm{B}(\mathrm{b}) \mathrm{f}=$ benzo(b)fluoranthene, $\mathrm{B}(\mathrm{k}) \mathrm{f}=$ benzo(k)fluoranthene, $\mathrm{B}(\mathrm{a}) \mathrm{P}=$ benzo(a)pyrene. $\mathrm{C} 1$, $\mathrm{C} 2, \mathrm{C} 3$, and $\mathrm{C} 4$ : alkylated homologs of parent compounds containing from 1 to 4 methyl side chains, respectively. Values are averages of 2 replicates

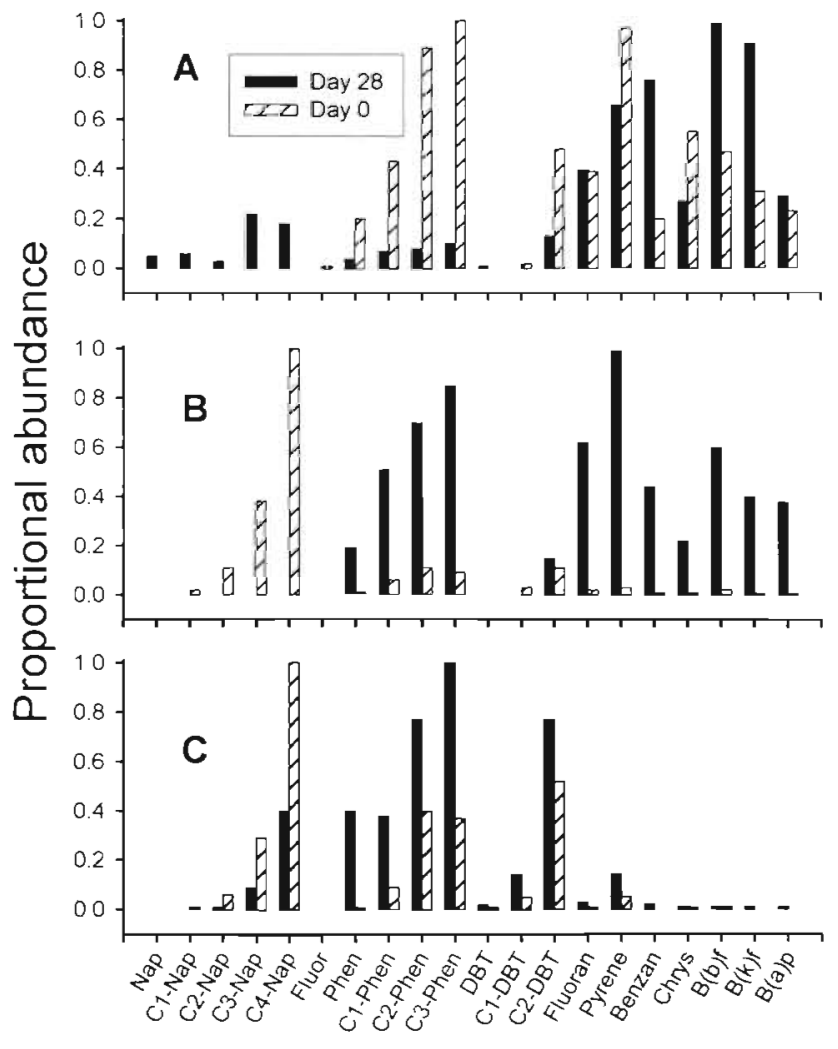

Fig. 2 Change in proportional abundance of major groups of PAH in (A) Low, (B) Medium, and (C) High treatments over the $28 \mathrm{~d}$ study period. Abbreviations as in Fig. 1. Values are averages of 2 replicates 
lene and C1-, C2-, and C3-naphthalenes were proportionately less abundant than they were in diesel-contaminated sediments (Fig. 1). The loss of these lowermolecular-weight compounds in microcosms was probably the result of rapid sediment-water exchange and volatilization. Low treatments (Fig. 2A) consisted of only a minor PAH addition to microcosms, and thus the proportional abundances of PAH were similar to those of controls, i.e. very little naphthalene (parent or alkylated) and relatively high abundances of 4 - and 5 ring compounds. The relatively high concentrations of phenanthrenes and C2-DBT were, however, evidence of the addition of diesel-contaminated sediments.

PAH composition in Day 28 microcosms differed substantially from Day 0 samples, and the degree of change differed among treatments (Fig. 2). In Day 28 Low treatments, the proportional abundance of phenanthrenes and C2-DBT was greatly reduced relative to Day 0 Low samples (Fig. 2A), and the profile closely resembled Day 0 control sediments (Fig. 1).

The alkylated naphthalenes that were abundant in Day 0 Medium treatments were completely eliminated by Day 28 (Fig. 2B). The proportional abundances of phenanthrenes and 4- and 5-ring compounds increased substantially by Day 28.

In High treatments, the compositional change of PAH from Day 0 to Day 28 was less dramatic than in Medium and Low treatments (Fig. 2C). Naphthalenes were reduced, but not eliminated as in Medium treatments. Phenanthrenes and DBT replaced naphthalenes as the dominant compounds, and, with the possible exception of pyrene, 4- and 5-ring $\mathrm{PAH}$ remained a minor component of total PAH composition.

\section{PAH concentration}

Average total PAH (from GC/MS measurements) in control microcosms (Cont1 and Cont2) was 0.26 ppm on Day 0 and 0.35 ppm on Day 28. Total PAH in Day 0 Low, Medium, and High treatments were 0.59, 7.7, and 9.4 ppm respectively (Table 1 ). Concentrations in Low and Medium treatments were similar to expected concentrations (calculated PAH concentration of contaminated sediment plus ambient concentration), but the value in High treatments did not represent the $10 \times$ increase over Medium treatments that was expected. As discussed below, this apparent discrepancy may have resulted from uneven distribution of diesel-contaminated sediments in Day 0 microcosms

In Medium treatments, concentration of all PAH containing $\leq 3$ rings decreased from Day 0 to Day 28, whereas the concentration of $4 / 64$ - and 5-ring compounds increased (Table 1). With a few notable excep- tions, changes in PAH concentrations in High treatments were similar to those observed in Medium treatments (Table 1). The concentrations of all alkylated naphthalenes decreased and, with the exception of C2-alkylated forms, the concentrations of all phenanthrenes and DBT decreased. As in Medium treatments 4/6 4- and 5-ring PAH increased in abundance over time in High treatments.

The concentration of 3-ring compounds decreased in Low treatments from Day 0 to Day 28 (Table 1). In contrast to Medium and High treatments, however, the concentrations of 4- and 5-ring compounds in Low treatments did not change substantially over time.

Measurements of total PAH by Iatroscan were generally higher than those determined from GC/MS, especially in the Day 0 High treatment. There are various possible explanations for this discrepancy. The first is related to calibration. The Iatroscan method that we used separated all PAH into a single peak. The PAH composition of our standard did not precisely match that of samples (the composition of which was variable), and variable detector responses to different compounds could have resulted in an overestimation of total PAH. Nevertheless, the measured total PAH concentration in Day 0 High treatments as determined from Iatroscan analysis $(69.7 \mathrm{ppm})$ was reasonably close to the calculated expected concentration of $55 \mathrm{ppm}$. The apparent discrepancy between Iatroscan and GC/MS could also have been the result of the high degree of variability that was detected in Day O High treatments. For example, latroscan values from individual replicates of Day 0 High treatments were 169.2, $97.9,6.0$, and $5.8 \mathrm{ppm}$. This variability could have been the result of an uneven distribution of diesel-contaminated sediments in microcosms immediately after contaminated sediments were added to microcosms. The 2 GC/MS samples corresponded to the 6.0 and $169.2 \mathrm{ppm}$ Iatroscan samples, and yielded values of 4.9 and 14.0 ppm respectively. Variability in Day 0 Iatroscan data from the High treatment could also have been a consequence of a loss of naphthalenes during processing of samples. We have observed that nonalkylated naphthalene is lost during the process of Chromarod development. Since naphthalene was less abundant after Day 0 , this source of variability was probably less important after Day 0. Collectively, however, PAH as determined by GC/MS was a good predictor of total PAH as determined by Iatroscan $\left(\mathrm{r}^{2}=\right.$ 0.89, data not shown). Thus, at a minimum, the Iatroscan provided a good relative indication of total PAH concentration.

Iatroscan data indicated that PAH in High treatments accumulated over the first week, then decreased by approximately one-half by Day 14, and again by one-half by Day 28 (Fig. 3). Total PAH in Medium 


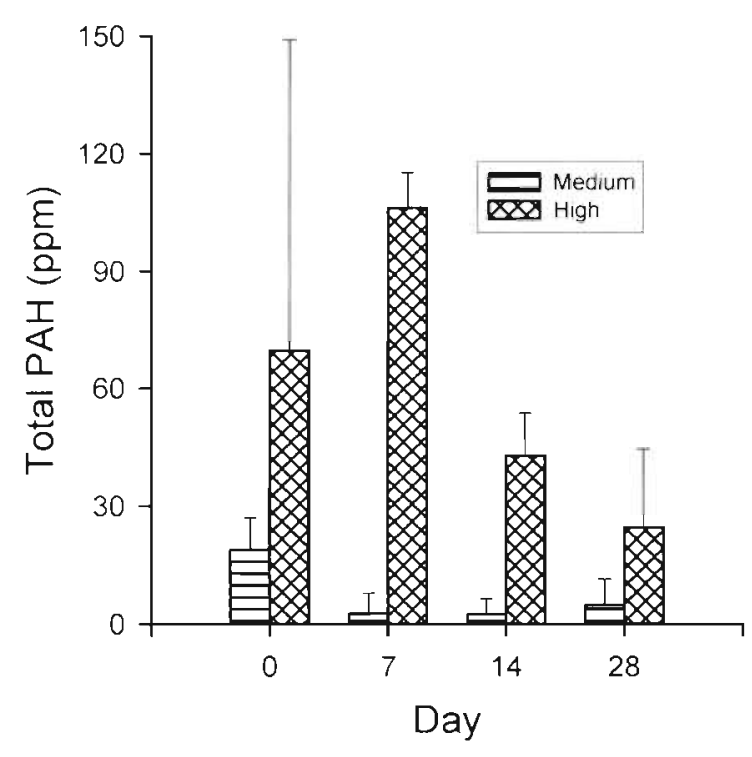

Fig. 3. Total PAH concentration in High and Medium treatments as determined by latroscan. Values are means $+1 \mathrm{SD}$ $(n=4)$

treatments decreased by a factor of approximately 7 by Day 7 and remained relatively constant thereafter (Fig. 3). These trends were qualitatively consistent with GC/MS data, which indicated that total PAH in Day 28 Medium treatments was only slightly greater than Day 0 controls, while total PAH in Day 28 High treatments was higher than Day 0 controls by a factor of 10 or more (Table 1). Thus, removal rate of PAH in Medium (and Low) treatments was equal to or exceeded the rate of addition. The removal rate of PAH from High treatments, however, was not sufficient to reduce PAH concentrations to background levels.

\section{Bacterial abundance}

Bacterial abundance in microcosms ranged from 0.27 to $2.8 \times 10^{9}$ cells g ${ }^{-1}$ dry wt throughout the experiment (Fig. 4). Bacterial abundance was not significantly affected by diesel-contaminated sediment ( $p=0.178)$, and there was no trend that was even suggestive of an effect. Bacterial abundance did vary significantly among days $(p<0.0001)$, with greatest numbers being detected on Day 7.

\section{Bacterial activity}

As with bacterial abundance, bacterial activity as determined by ${ }^{14} \mathrm{C}$-acetate incorporation into phospholipids, or the phospholipid:PHA (poly- $\beta$-hydroxyalkanoates) ratio of ${ }^{14} \mathrm{C}$-acetate incorporation (Findlay \& White 1987) were not significantly influenced by

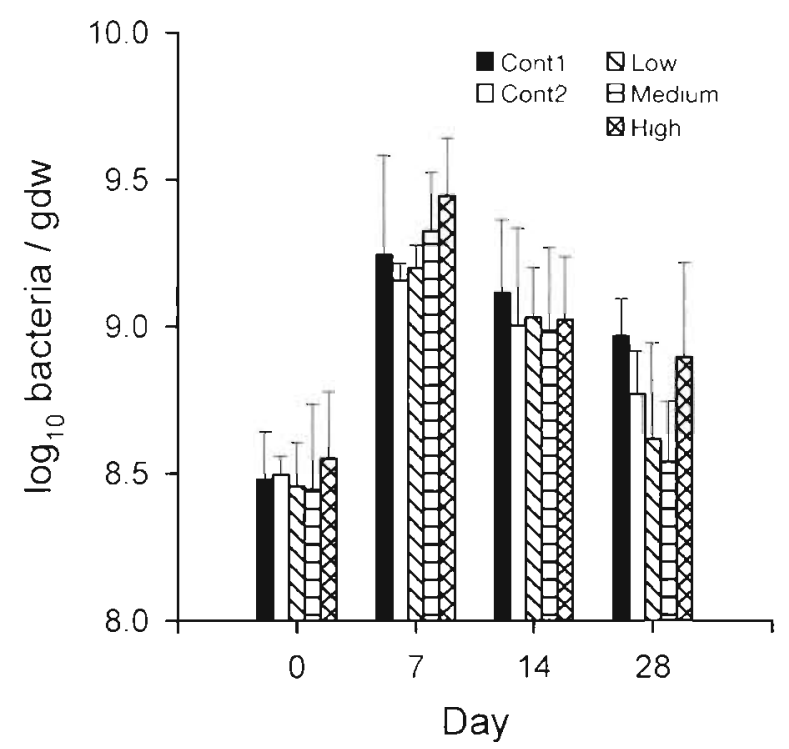

Fig. 4. Bacterial abundance in sediments exposed to a range of diesel contamination over a $28 \mathrm{~d}$ period. Values are means $+1 \mathrm{SD}(n=4)$

diesel-contaminated sediment $(p=0.674$ and 0.739 , respectively; Fig. 5). Similarly, ${ }^{3} \mathrm{H}$-leucine incorporation into protein (measured on Day 28 only) was remarkably consistent among treatments (Fig. $6 ; p=$ $0.742)$.
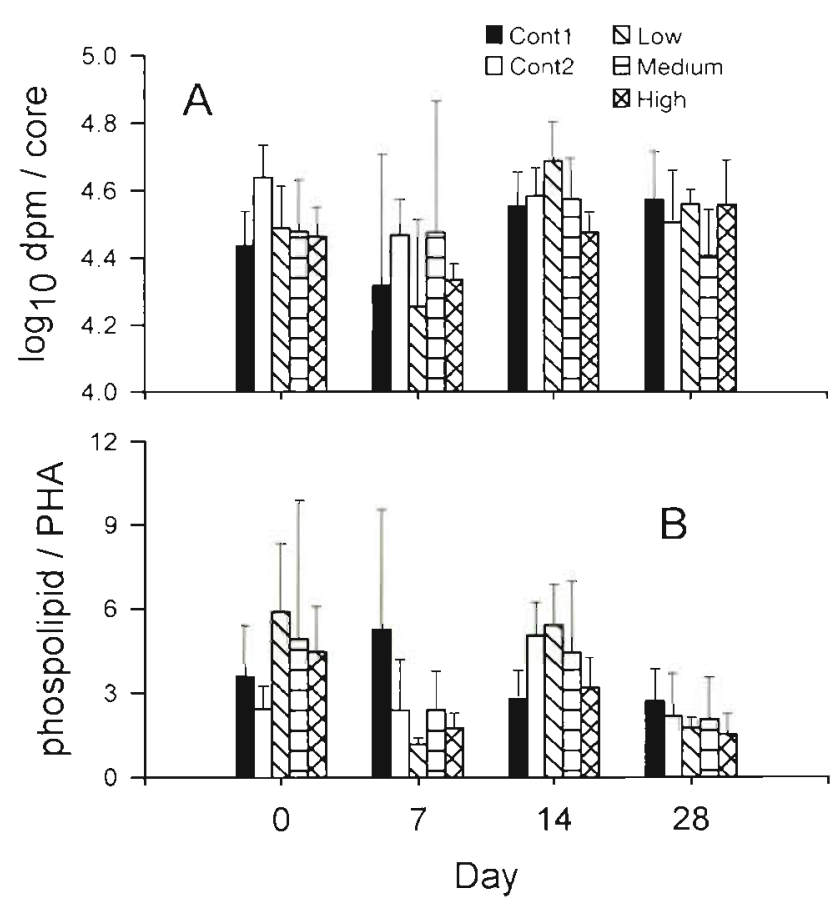

Fig. $5 .{ }^{14} \mathrm{C}$-acetate metabolism in sediments exposed to a range of diesel contamination over a $28 \mathrm{~d}$ period. (A) Incorporation of ${ }^{14} \mathrm{C}$ into phospholipids. (B) Phospholipid/PHA ratio of ${ }^{14} \mathrm{C}$ incorporation. Values are means $+1 \mathrm{SD}(\mathrm{n}=4)$ 


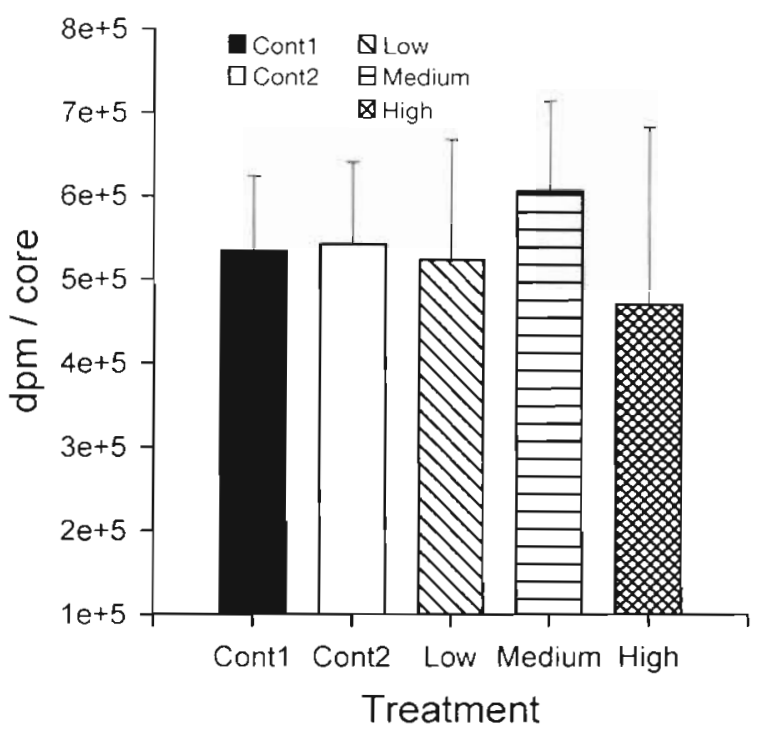

Fig 6. ${ }^{3} \mathrm{H}$-leucine incorporation into protein in sediments exposed to a range of diesel contamination on Day 28 of the experiment. Values are means $+1 \mathrm{SD}(n=4)$

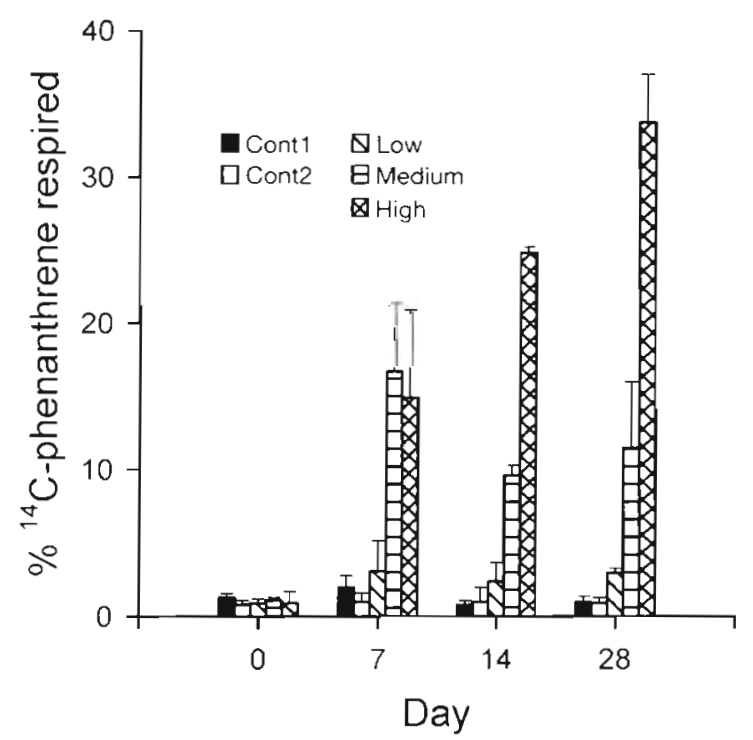

Fig. 7. Conversion of ${ }^{14} \mathrm{C}$-phenanthrene to ${ }^{14} \mathrm{CO}_{2}$ in sediments exposed to a range of diesel contamination over a $28 \mathrm{~d}$ period. Sediments were incubated for $72 \mathrm{~h}$ at $27^{\circ} \mathrm{C}$. Values are means $+1 \mathrm{SD}(\mathrm{n}=4)$

\section{PAH metabolism}

In contrast to bacterial abundance and assays of bacterial activity, bacterial degradation of ${ }^{14} \mathrm{C}$-phenanthrene was sensitive to diesel-contaminated sediment (Fig. 7). In Day 0 microcosms, degradation of ${ }^{14} \mathrm{C}$ phenanthrene was low but detectable $(0.9$ to $1.3 \%$ of total available over a $72 \mathrm{~h}$ period) and did not differ among treatments. Degradation rates of ${ }^{14} \mathrm{C}$-phenan- threne remained relatively low in both controls (Cont1 and Cont 2 ) over the entire course of the experiment (range 0.8 to $2.0 \%$ ). Dose-dependent enhancement of phenanthrene degradation in all diesel treatments (Low, Medium, and High) occurred from Day 7 through Day 28. The enhancement of ${ }^{14} \mathrm{C}$-phenanthrene degradation was statistically significant in Medium and High treatments when performing ANOVA on the entire data set, and when considering Days 7 through 28 individually $(p<0.0001)$. Degradation of ${ }^{14} \mathrm{C}$-phenanthrene in Low treatments was significantly higher than in controls only on Day 28. After Day 7 , the enhancement of ${ }^{14} \mathrm{C}$-phenanthrene degradation in Low and Medium treatments remained constant or was slightly diminished. ${ }^{14} \mathrm{C}$-phenanthrene degradation in High treatments continued to increase throughout the experimental period.

\section{DISCUSSION}

Our observations on the effects of diesel on Gulf of Mexico sedimentary bacteria appear to be generally consistent with previous studies of individual PAH or crude oils. Even at the highest doses (ca 55 ppm PAH), diesel-contaminated sediment had no detectable influence on bacterial incorporation of ${ }^{14} \mathrm{C}$-acetate or ${ }^{3} \mathrm{H}$ leucine, or on bacterial abundance. In a microcosm study similar in design to that reported here, PAH-contaminated sediments from a produced-water (contaminated water released from oil-production activities) site in the Gulf of Mexico also failed to elicit a change in sedimentary bacterial abundance or metabolism of ${ }^{14} \mathrm{C}$ acetate (Carman et al. 1995). Nor did diesel-contaminated sediments have an influence on the physiological condition of the bacterial community as indicated by the relative incorporation of ${ }^{14} \mathrm{C}$-acetate into phospholipids and PHA. Our experimental manipulations could have potentially produced both a physical (addition of sediment) and a chemical (addition of hydrocarbons) disturbance to benthic microorganisms. Nevertheless, no evidence of disturbance was detected.

Failure to detect changes in bacterial abundance or metabolic activity, however, does not mean that the bacterial community was unaffected by addition of hydrocarbons. Indeed, Baker \& Griffiths (1984) proposed that evolved resistance to environmental contaminants may be responsible for variability in responses of sedimentary microorganisms to petroleum hydrocarbons. Further, Griffiths et al. (1981b) proposed that the insensitivity of Gulf of Mexico bacteria to petroleum hydrocarbons is the result of adaptation to chronic exposure from years of oil-production activities in the area.

Cerniglia \& Heitkamp (1989) proposed that microbial adaptation to PAH contamination occurs as a 2 - 
step process: (1) acutely toxic low-molecular-weight $\mathrm{PAH}$ (such as naphthalene) eliminates sensitive microbes, and (2) resistant microbes that can metabolize PAH undergo a period of increased growth/activity. Our observations are partially consistent with this hypothesis. First, we observed no evidence of acute (or chronic) toxicity. Neither bacterial metabolic activity nor bacterial abundance was significantly influenced by diesel after short (Day 0 or Day 7) periods of exposure. Thus, any mortality or suppression of activity that might have occurred was below the sensitivity of our techniques. It is worth noting, however, that with approximately $10^{9}$ bacteria $\mathrm{g}^{-1}$ of sediment, it is possible to eliminate or add millions of bacteria and not detect the change in a typical direct-count procedure. The second part of Cerniglia \& Heitkamp's hypothesis is generally supported by our observations. Bacterial metabolism of ${ }^{14} \mathrm{C}$-phenanthrene dramatically increased over time in a dose-dependent pattern, implying that a PAH-degrading assemblage of bacteria developed in response to the presence of diesel-contaminated sediments. Again, however, we detected no significant change in total bacterial abundance that was related to diesel contamination, suggesting that (1) growth of PAH-degrading bacteria was offset by mortality of other bacteria, (2) existing bacteria have the capacity to metabolically switch to PAH degradation, or (3) the total number of PAH-degrading bacteria was insignificant relative to the total bacterial community.

Although ${ }^{14} \mathrm{C}$-phenanthrene degradation rates were relatively low at Day 0 , degradation was nevertheless detectable $\left(0.30\right.$ to $\left.0.43 \% \mathrm{~d}^{-1}\right)$. Using estuarine sediments from New York, Bauer \& Capone (1985b) observed that ${ }^{14} \mathrm{C}$-anthracene (another 3-ring aromatic) degradation was only $0.01 \% \mathrm{~d}^{-1}$ even after $4 \mathrm{~d}$ of exposure at $100 \mathrm{ppm}$. Thus, it would appear that ambient bacteria in this Louisiana salt marsh exhibit some significant level of preadaptation to PAH. Nevertheless, even modest (0.55 ppm) additions of diesel elicited significant elevations of phenanthrene degradation. In the Low and Medium treatments, the rate of ${ }^{14} \mathrm{C}$-phenanthrene degradation peaked by $1 \mathrm{wk}$, and remained constant thereafter. ${ }^{14} \mathrm{C}$-phenanthrene degradation in High treatments, however, continued to increase throughout the experiment, and reached a rate of $11.2 \% \mathrm{~d}^{-1}$ by Day 28 . For comparison, Bauer \& Capone (1985b) reported a maximum degradation rate for anthracene of $3.9 \% \mathrm{~d}^{-1}$. Further, the maximum phenanthrene degradation rates reported here are comparable to the maximum rates of naphthalene (a much more labile PAH) degradation $\left(10 \% \quad \mathrm{~d}^{-1}\right)$ reported by Bauer \& Capone (1985b).

The continued acceleration of phenanthrene degradation in High treatments apparently occurred because the supply of hydrocarbons outpaced the rate at which they were metabolized. Specifically, PAH in Day 28 High treatments were still highly enriched in alkylated $\mathrm{PAH}$, including naphthalenes, phenanthrenes, and DBT, indicating the presence of unmetabolized petroleum hydrocarbons

We also observed that alkylated PAH, which are generally diagnostic of petroleum hydrocarbons, were readily removed from sediments. Relatively little information is available concerning the metabolism of alkylated versus parent PAH. Cerniglia \& Heitkamp (1989) observed that 2-methylnaphthalene was metabolized much slower than naphthalene or phenanthrene. Our data suggest that even highly methylated naphthalene (C4) was readily metabolized, as were alkylated forms of other PAH (i.e. phenanthrenes and dibenzothiophenes). In Low and Medium treatments, parent and alkylated naphthalenes, phenanthrenes, and DBT were removed completely or almost completely over the $28 \mathrm{~d}$ study period. The rate of decrease in parent phenanthrene and DBT in Low and Medium treatments was lower than the rates of decrease in alkylated forms. In the High treatment, parent phenanthrene and DBT increased by approximately a factor of 15 and 1.4 respectively, whereas accumulation of alkylated phenanthrenes and DBT was generally much lower (Table 1). This implies that the removal of PAH was not simply a desorption phenomenon (Means et al. 1980, Means \& Wijayaratne 1984, Means \& McMillin 1993, Means in press); if such were the case, higher molecular weight (alkylated) compounds would have been removed more slowly. Thus, microbial degradation must have contributed significantly to the removal of 2- and 3-ring parent and alkylated $\mathrm{PAH}$, and alkylated PAH showed no evidence of being disproportionately resistant to microbial degradation.

Previous studies have suggested that DBT may provide a reliable marker for petroleum-hydrocarbon contamination because they are found in all types of petroleum (Clark 1989, Steinhauer et al. 1994), including diesel (Williams et al. 1986), and they are considered to be resistant to photochemical (Andersson 1993) and microbial (Sinkkonen 1989) degradation. In the present study, however, DBT were at least as susceptible to microbial degradation as were phenanthrenes. Over the $28 \mathrm{~d}$ study, essentially all DBT were removed from Low and Medium treatments, thus leaving no evidence of diesel contamination. Fayad \& Overton (1995) also observed high rates of DBT degradation in sediments contaminated during the 1991 Gulf War. In particular, they observed that C2- and C3-DBT were degraded more quickly than C1-DBT, an observation that is consistent with our data (Table 1). Our data also show that, in High treatments, the rate of accumulation of DBT was much less than that of phenanthrenes. Thus, our data indicate that DBT were metabolized by sedimen- 
tary bacteria at a high rate, and that DBT would not accumulate in these sediments unless very high rates of input were maintained.

Collectively, our data indicate that the Louisiana salt marsh bacterial community studied here is symptomatic of one that has been chronically exposed to petroleum hydrocarbons: bacterial abundance and general assays of bacterial metabolism are insensitive to additions of diesel, ambient bacteria can metabolize $\mathrm{PAH}$ at substantial rates, and the PAH-degrading portion of the community responds quickly to additions of petroleum hydrocarbons. It is possible that the PAHdegrading bacterial community maintains ambient sedimentary PAH concentrations at relatively low levels. In Low and Medium treatments, no significant accumulation of PAH could be detected over the $28 \mathrm{~d}$ period relative to ambient sediment. Further, PAH concentration in High treatments were reduced by approximately $43 \%$ over the $28 \mathrm{~d}$ experiment, despite the daily addition of diesel-contaminated sediment.

These observations of the bacterial response to diesel contamination have implications for understanding how ecosystems respond to contamination by crude or refined petroleum hydrocarbons. One possibility is that rapid bacterial metabolism of petroleum hydrocarbons could ultimately reduce exposure of other benthic organisms to potentially toxic compounds. We have observed that the meiofaunal/microbial foodweb in this salt marsh is relatively resistant to petroleum-hydrocarbon contamination from produced water (Carman et al. 1995) or diesel (Carman unpubl.). Further study will be required to determine if the apparent insensitivity of this benthic food web is because the fauna itself is resistant to hydrocarbons, or if it relies on bacterial detoxification of petroleum contaminants.

Acknowledgements. We thank J. Cline, J. Fleeger, C. Gregg, B. Hughes, T Huynh, M. McCall, D. McMillin, M. Pace, S. Rai, and A. Todaro for technical assistance in the field and lab. The research was supported by Office of Naval Research grant N00014-93-1-0975 and Mineral Management Service grant 14-35-0001-30660

\section{LITERATURE CITED}

Ackman RG, McLeod CA, Banerjee AK (1990) An overview of analyses by Chromarod-latroscan TLC-FID. J Planar Chromatogr 3:450-490

Alexander SK, Schwarz JR (1980) Short-term effects of South Loussiana and Kuwait crude oils on glucose utilization by marine bacterial populations. Appl Environ Microbiol 40: $341-345$

Andersson JT (1993) Polycyclic aromatic sulfur heterocycles III. Photochemical stability of the potential oil pollution markers and dibenzothiophenes. Chemosphere 11. 2097-2102
Baker JH, Griffiths RP (1984) Effects of oil on bacterial activity in marine and freshwater sediments. In: Engelhardt FR (ed) Petroleum effects in the Arctic environment. Elsevier, London, p 63-99

Bartha R, Atlas RM (1987) Transport and transformations of petroleum: biological processes. In: Boesch DF, Rabalais NN (eds) Long-term environmental effects of offshore oil and gas development. Elsevier, London, p 287-342

Bauer JE, Capone DG (1985a) Effects of four aromatic organic pollutants on microbial glucose metabolism and thymidine incorporation in marine sediments. Appl Environ Microbiol 49:828-835

Bauer JE, Capone DG (1985b) Degradation and mineralization of the polycyclic aromatic hydrocarbons anthracene and naphthalene in intertidal marine sediments. Appl Environ Microbiol 50:81-90

Bauer JE, Kerr RP, Bautista MF, Decker CJ, Capone DG (1988) Stimulation of microbial activities and polycyclic aromatic hydrocarbon degradation in marine sediments inhabited by Capitella capitata. Mar Environ Res 25:63-84

Bunch JN (1987) Effects of petroleum releases on bacterial numbers and microheterotrophic activity in the water and sediment of an Arctic marine ecosystem. Arctic 40: $172-183$

Carman KR (1993) Microautoradiographic detection of microbial activity. In: Kemp PF, Sherr BF, Sherr EB, Cole JJ (eds) Handbook of methods in aquatic microbial ecology. Lewis Publishers, Boca Raton, p 397-404

Carman KR, Dobbs FC, Guckert JB (1988) Consequences of thymidine catabolism for estimates of bacterial production: an example from a coastal marine sediment. Limnol Oceanogr 33:1595-1606

Carman KR, Fleeger JW, Means JC, Pomarico SM, MCMillin DJ (1995) Experimental investigation of the effects of polynuclear aromatic hydrocarbons on an estuarine sediment food web. Mar Environ Res 40:289-318

Cerniglia CE, Heitkamp MA (1989) Microbial degradation of polycyclic aromatic hydrocarbons (PAH) in the aquatic environment. In: Varanasi U (ed) Metabolism of polycyclic aromatic hydrocarbons in the aquatic environment. CRC Press, Inc., Boca Raton, p 41-68

Chandler GT (1986) High-density culture of meiobenthic harpacticoid copepods within a muddy sediment substrate. Can J Fish Aquat Sci 43:53-59

Chandler GT, Fleeger JW (1983) Meiofaunal colonization of azoic estuarine sediment in Louisiana: mechanisms of dispersal. J Exp Mar Biol Ecol 69:175-188

Clark RB (1989) Marine pollution. Clarendon Press, Oxford, p $1-220$

Connell DW, Miller GJ (1984) Chemistry and ecotoxicology of pollution. John Wiley \& Sons, New York, p 1-444

Dobbs FC, Guckert JB, Carman KR (1989) Comparison of three techniques for administering radıolabeled substrates to sediments for trophic studies: incorporation by mirrobes. Microb Ecol 17:237-250

Fayad NM, Overton E (1995) A unique biodegradation pattern of the oil spilled during the 1991 Gulf War. Mar Pollut Bull 30:239-246

Findlay RH, White DC (1987) A simplified method for bacterial nutritional status based on the simultaneous determination of phospholipid and endogenous storage lipid poly- $\beta$-hydroxyalkanoate. J Microbiol Methods 6: $113-120$

Griffiths RP, Caldwell BA, Broich WA, Morita RY (1981a) Long-term effects of crude oil on uptake and respiration of glucose and glutamate in Arctic and subarctic marine sediments. Appl Environ Microbiol 42:792-801 
Griffiths RP, McNamara TM, Caldwell BA, Morita RY (1981b) Field observations on the acute effect of crude oil on glucose and glutamate uptake in samples collected from Arctic and subarctic waters. Appl Environ Microbiol 41: $1400-1406$

Guckert JB, Antworth CP, Nichols PD, White DC (1985) Phospholipid, ester-linked fatty acid profiles as reproducible assays for changes in prokaryotic community structure of estuarine sediments. FEMS Microbiol Ecol 31:147-158

Heitkamp MA, Cerniglia CE (1988) Mineralization of polycyclic aromatic hydrocarbons by a bacterium isolated from sediment below an oil field. Appl Environ Microbiol 54 $1612-1614$

Hobbie JE, Daley RJ, Jasper S (1977) Use of nucleopore filters for counting bacteria by fluorescence microscopy. Appl Environ Microbiol 33:1225-1228

Jamison VM, Raymond RL, Hudson JO (1976) Biodegradation of high-octane gasoline. In: Sharpley JM, Kaplan AM (eds) Proceedings of the third international biodegradation symposium. Applied Science Publishers, Ltd., London, p $187-196$

Kennish MJ (1992) Polynuclear aromatic hydrocarbons. In Ecology of estuaries. CRC Press, Boca Raton, p 133-181

Little DI (1987) The physical fate of weathered crude and emulsified fuel oils as a function of intertidal sedimentology. In: Kuiper J, van den Brink WJ (eds) Fate and effects of oil in marine ecosystems. Martinus Nijhoff Publishers, Boston, p 3-18

MacGillivray AR, Shiaris MP (1994) Relative role of eukaryotic and prokaryotic microorganisms in phenanthrene transformation in coastal sediments. Appl Environ Microbiol 60:1154-1159

MacLeod WD, Brown DW, Friedman AJ, Burrows DG, Maynes O, Pearce RW, Wigren CA, Bogar RG (1985) Standard analytical procedures of the NOAA National Analytical Facility, 1985-1986. NOAA Tech Memo NMFA F/NWC -92

Means JC (1995) Influence of salinity upon sediment-water partitioning of aromatic hydrocarbons. Mar Chem 50: $3-16$

Means JC, McMillin DJ (1993) Fate and transport of particlereactive normal, alkylated and heterocyclic aromatic hydrocarbons in a sediment-water-colloid system. Gulf of Mexico Study/MMS 93-0018. U.S. Department of the Inte-

Responsible Subject Editor: F. Azam, La Jolla, California, USA rior, Minerals Management Service, Gulf of Mexico OCS Regional Office, New Orleans, LA, p 1-150

Means JC, Wijayaratne RD (1984) Chemical composition of estuarine colloidal organic matter implications for sorptive processes. Bull Mar Sci 35:449-461

Means JC, Wood SG, Hassett JJ, Banwart WL (1980) Sorption properties of polynuclear aromatic hydrocarbons by sediments and soils. Environ Sci Technol 14:1524-1528

National Research Council (1985a) Inputs. In: Oll in the sea: inputs, fates, and effects. National Academy Press, Washington, DC, p 43-88

National Research Council (1985b) Effects. In: Oil in the sea: inputs, fates, and effects. National Academy Press, Washington, DC, p 369-547

National Research Council (1985c) Chemical composition of petroleum hydrocarbon sources. In: Oil in the sea: inputs, fates, and effects. National Academy Press, Washington, DC, p $17-42$

National Toxicology Program (1986) Toxicology and carcinogenesis studies of marine diesel fuel and JP-5 Navy fuel in B6C3F $_{1}$. NTP Tech Rep NTP TR 310

Samiullah Y (1985) Biological effects of marine oil pollution. Oil Petrochem Pollut 2:235-264

Sinkkonen S (1989) The fate of some crude oil residues in sediments. Chemosphere 18:2093-2100

Steinhauer MS, Boehm PD (1992) The composition and distribution of saturated and aromatic hydrocarbons in nearshore sediments, river sediments, and coastal peat of the Alaskan Beaufort Sea: implications for detecting anthropogenic hydrocarbon inputs. Mar Environ Res 33: 223-253

Steinhauer M, Crecelius E, Steinhauer W (1994) Temporal and spatial changes in the concentrations of hydrocarbons and trace metals in the vicinity of an offshore oil-production platform. Mar Environ Res 37:129-163

White DC, Davis WM, Nickels JS, King JD, Bobbie RJ (1979) Determination of sedimentary microbial biomass by extractible lipid phosphate. Oecologia 40:51-62

Williams PT, Bartle KD, Andrews GE (1986) The relation between polycyclic aromatic compounds in diesel fuels and exhaust particulates. Fuel 65:1150-1158

Wyndham RC (1985) Adaptation of estuarine bacteria to toluene at low concentrations in seawater: cometabolism of toluene. Can J Microbiol 31:910-918

Manuscript first received: December 13, 1995

Revised version accepted: March 25, 1996 